\title{
Normal anatomic variants of paranasal sinus region studied by computed tomography
}

\begin{abstract}
Background and objective: Variation in paranasal sinus anatomy, as shown on computed tomographic scans, is of potential significance as it may pose risks during surgery or predispose to certain pathologic conditions. This study aimed to investigate the frequency of anatomic variants of the nasal cavity and paranasal sinuses in our population and determine their relationship with gender and find out the association of these variants with mucosal abnormalities.
\end{abstract}

Methods: This was a cross-sectional study conducted at the College of Medicine, Hawler Medical University from October 2017 to January 2019. A review of computed tomography scans of the paranasal sinuses of 300 patients was done; special attention was directed toward identifying bony anatomic variants and mucosal abnormalities.

Results: Frequent variants were: Agger nasi cells (72\%), nasal septal deviation $(71.7 \%)$, Haller cells $(70.7 \%)$, concha bullosa $(61 \%)$, elongation of uncinate process $(69.7 \%)$ and different variants of the sphenoidal sinus $(78.8 \%)$. The frequency of variants did not differ significantly with respect to gender, except for sphenoidal variants along with Keros types and asymmetry of the ethmoidal roof. A significant association was found between middle concha variants and inferior turbinate enlargement $(P<0.001)$.

Conclusion: Anatomic variants of the paranasal sinus region were common in our population; the most frequent ones were those involving the nasal septum, ethmoid air cells, sphenoid sinuses, and middle turbinates. The study of these variants is important for the management of paranasal sinus region disease.

Keywords: Anatomic variants; Paranasal sinuses; Computed tomography.

\section{Introduction}

Paranasal sinus (PNS) region anatomy differs significantly among individuals; certain anatomic variants are frequently seen on sinus computed tomography (CT) scans. The most common ones are Agger nasi cells, infraorbital ethmoidal (Haller) cells, sphenoethmoidal (Onodi) cells, nasal septal deviation (NSD), septal bony spur, concha bullosa (CB) and paradoxical middle turbinate. ${ }^{1-10}$ Less common anatomic variants of the PNS region include pneumatization of the uncinate process, large ethmoidal bulla, superior turbinate pneumatization, and pneumatized crista galli. ${ }^{3,5,11-14}$ Some of the anatomic variants have been reported to be associated with chronic rhinosinusitis, possibly leading to inflammation by obstructing drainage pathways from the sinuses and nasal cavity. ${ }^{2-5}$ However, a number of other studies did not show a significant association between these anatomic variants and rhinosinusitis. ${ }^{1,4,9,10,15,16}$ Moreover, it has been reported that failure to recognize certain anatomic variants such as asymmetry of the ethmoidal roof, Onodi cells, pneumatization of anterior clinoid processes, supraorbital cells, Haller cells, pneumatization of the dorsum sella and dehiscence of the lamina papyracea may lead to complications during surgery due to proximity of blood vessels, nerves, brain, 
and orbits. $^{17-20}$ The frequency of these variants may differ among the different ethnic groups. ${ }^{21}$ There is no data on anatomic variants of the PNS region in our population in the literature review. This study aimed to investigate the frequency of a number of anatomic variants of the PNS region in our population, find out their gender distribution and the association of these variants with mucosal abnormalities, and compare the results with previous investigations conducted in different populations. The end goal was to gather this knowledge in an effort to reduce the rate of complications of endoscopic sinus surgery.

\section{Methods}

This was a cross-sectional study conducted at the College of Medicine, Hawler Medical University from October 2017 to January 2019. The study protocol was approved by the Research Ethical Committee of the college. It comprised a review of 350 cases with unenhanced PNS CT scans at Rizgary teaching hospital using Siemens SOMATOM Emotion16-slice multidetector CT scanner. All scans were performed for evaluation of a symptom related to the PNS region. After excluding those below 18 years, previous nasal or paranasal sinus surgery, neoplastic disease, a history of nasal trauma or facial anomaly, and extensive opacification of PNSs that distorted the normal anatomy, the CT findings of the remaining 300 patients were analyzed. All scans were obtained using a bone algorithm in axial complemented by coronal and sagittal reconstructions with a slice thickness of $0.6 \mathrm{~mm}$ in most cases and kept $3 \mathrm{~mm}$ at maximum. Two independent observers assessed the scans. In cases of discrepancy between them, a third observer participated in the discussion to obtain an agreed decision. In all cases, the existence of the following variants was investigated: (1) nasal septum: septal deviation, septal bony spur, and pneumatization; (2) turbinates: middle turbinate pneumatization or concha bullosa
(CB), paradoxical (false) middle concha, hypoplasia; (3) ethmoid air cells: Agger nasi cells, Haller cells, and Onodi cells; (4)ethmoid uncinate process: elongation of the upper edge, pneumatization; (5) sphenoid sinus variants and (6) other variants: maxillary or frontal sinus septa or hypoplasia. The depth of olfactory fossa was classified according to the grading system proposed by Keros into three types. $^{22}$ The asymmetry of ethmoidal roof and incidence of aerated crista galli was also investigated. The summation of the unilateral and bilateral abnormalities has been reported as the prevalence of variants without considering the "half-head" as a separate entity. The images were also analyzed for the presence of mucosal abnormalities, including PNS mucosal thickening and inferior turbinate enlargement indicative of rhinosinusitis.

\section{Statistical Analysis}

The statistical package for the social sciences software, version 21 (Chicago; IL, USA) was used for data entry and analysis. A descriptive approach was used to determine frequency and percentages while in analytic approach (Chi-square test) was used for categorical variables. A $P$ value of $<0.05$ was considered statistically significant. The results were compared with studies published in the literature that aimed to detect the same anatomic variants using the CT scan. Images of some interesting cases were illustrated.

\section{Results}

Of the initial 350 scans, 50 were excluded for not meeting the inclusion criteria. The final sample size, as such, was 300 . The mean age of the patients was $33.36 \pm 13.15$ years, ranging from 18 to 69 years. There were 161 females $(53.7 \%)$ and 139 males $(46.3 \%)$. In all scans studied, one or more anatomic variants were identified. Asymmetry of the sphenoid cavities corresponding to the sphenoid sinus was observed in all, so it was not considered as an anatomic variant. The frequencies of 
a number of the anatomic variants are shown in Table 1. Frequent variants were Agger nasi cells (72\%), NSD (71.7\%), Haller cells $(70.7 \%)$, CB $(61 \%)$ and different forms of sphenoid variants $(78.7 \%)$ as shown in Figures 1 and 2.

Table 1: Frequency of certain anatomic variants in the studied sample.

\begin{tabular}{|c|c|c|}
\hline Anatomic Variants & Number & $\%(\mathrm{~N}=300)$ \\
\hline \multicolumn{3}{|l|}{ Nasal septal variants } \\
\hline NSD & 215 & 71.7 \\
\hline Septal spur & 102 & 34.0 \\
\hline Septal pneumatization & 50 & 16.7 \\
\hline \multicolumn{3}{|l|}{ Middle turbinate variants } \\
\hline $\mathrm{CB}$ & 183 & 61.0 \\
\hline Paradoxical turbinate & 57 & 19.0 \\
\hline Hypoplastic turbinate & 3 & 1.0 \\
\hline Aggernasi cells & 216 & 72.0 \\
\hline Haller cells & 212 & 70.7 \\
\hline Onodi cells & 134 & 44.7 \\
\hline \multicolumn{3}{|l|}{ Ethmoid Uncinate process } \\
\hline Elongation & 209 & 69.7 \\
\hline Pneumatization & 9 & 3.0 \\
\hline Frontal sinus agenesis or hypoplasia & 35 & 11.7 \\
\hline \multicolumn{3}{|l|}{ Keros classification } \\
\hline Type I & 93 & 31.0 \\
\hline Type II & 200 & 66.7 \\
\hline Type III & 7 & 2.3 \\
\hline Ethmoidal roof asymmetry & 130 & 43.3 \\
\hline Sphenoidal variants & 236 & 78.7 \\
\hline Crista galli pneumatization & 17 & 5.7 \\
\hline \multicolumn{3}{|l|}{ Maxillary sinus } \\
\hline Hypoplasia & 4 & 1.3 \\
\hline Septum & 75 & 25.0 \\
\hline
\end{tabular}




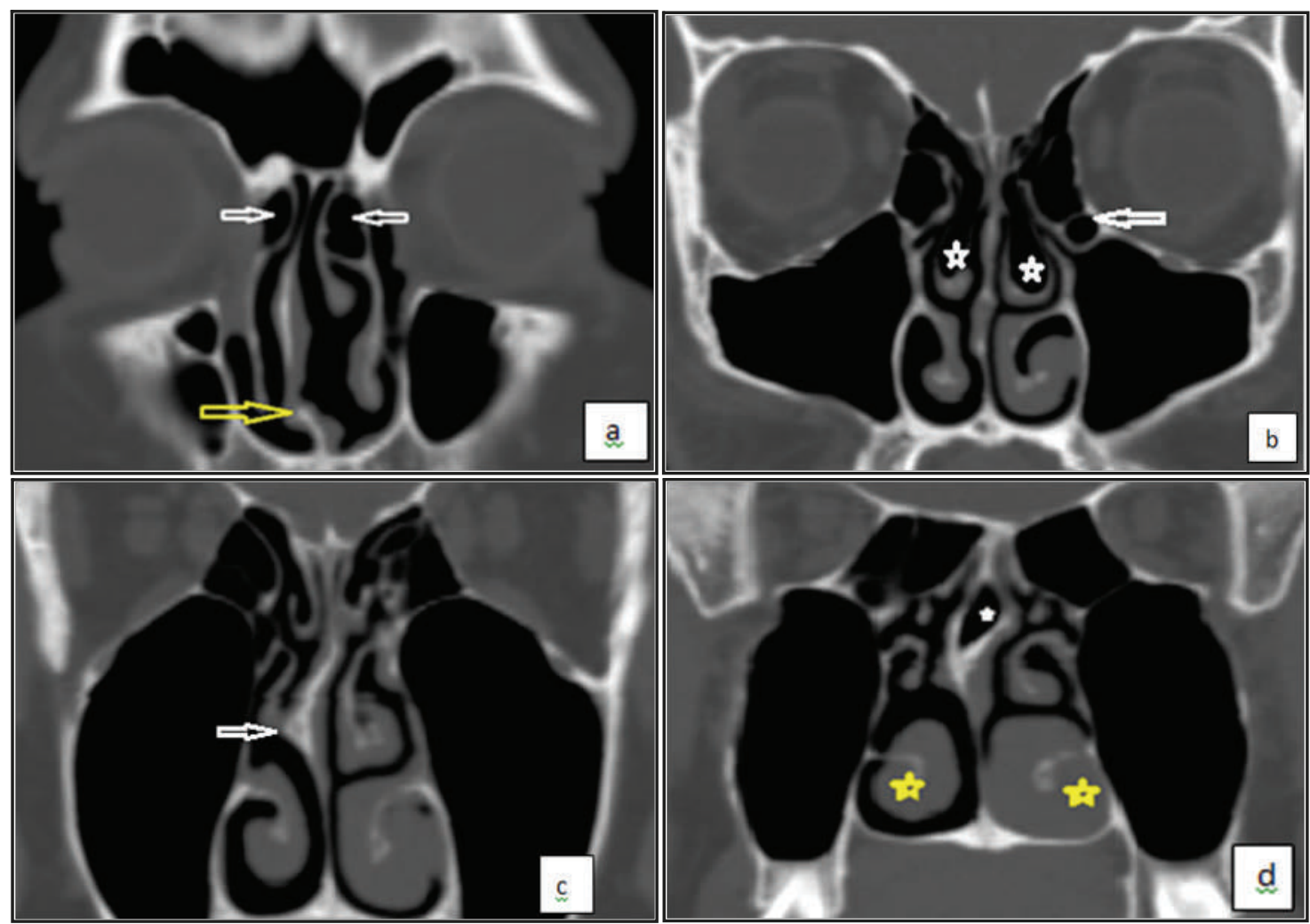

Figure 1: Coronal non-contrast computed tomography images in the bone window. (a) Bilateral Agger nasi cells (white arrows) and nasal septal deviation to the right (yellow arrow); (b) Bilateral concha bullosa (stars) and Haller cell (white arrow); (c) Nasal septal deviation to the right with spur; (d) Septal pneumatization (white star) and bilateral inferior turbinate enlargement more severe at the left (yellow stars).

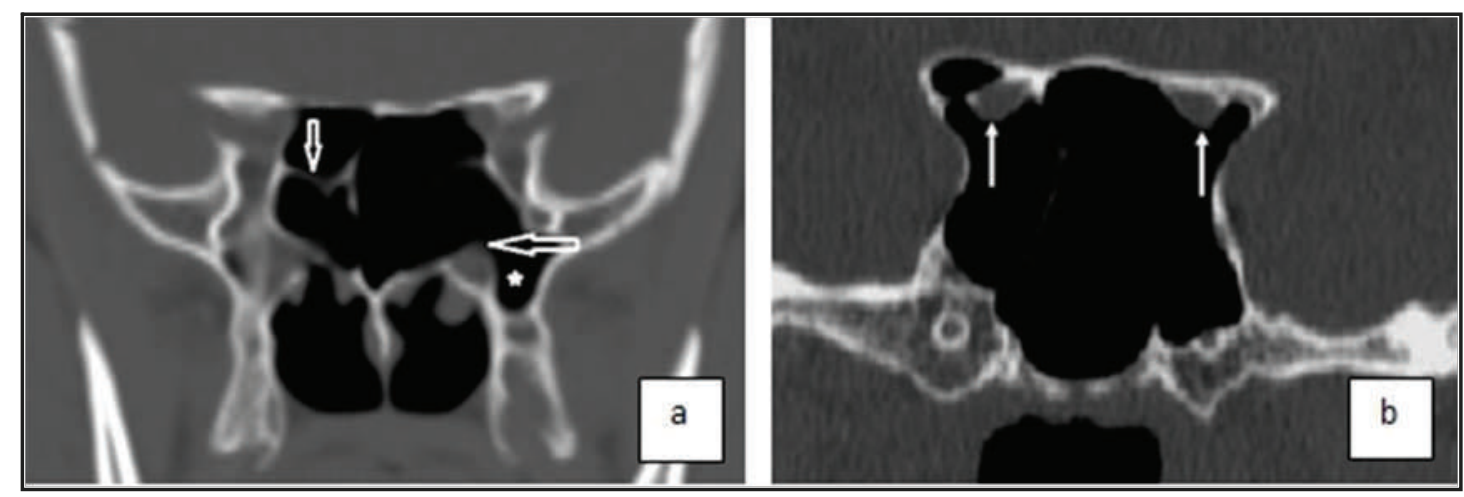

Figure 2: Coronal CT images of sphenoid sinus variants: (a) pneumatization of the left pterygoid processes (star) with protrusion and partial dehiscence of the left vidian nerve (horizontal arrow) and septum deviated to the right (vertical arrow); it is seen to insert over the bone covering the right internal carotid artery; (b) protrusion and partial dehiscence of the optic nerves (arrows). 
The frequency of anatomic variants did not differ significantly with respect to gender, except for sphenoidal variants along with
Keros types and ethmoidal roof asymmetry $(P<0.001)$, as shown in Table 2.

Table 2: Prevalence of certain anatomic variants by gender.

\begin{tabular}{|c|c|c|c|c|}
\hline \multirow[t]{2}{*}{ Variables } & \multicolumn{2}{|c|}{ Gender } & \multirow{2}{*}{$\begin{array}{c}\text { Total } \\
(\mathrm{N}=300)\end{array}$} & \multirow[t]{2}{*}{$P$ value } \\
\hline & $\begin{array}{c}\text { Male } \\
\text { No. (\%) }\end{array}$ & $\begin{array}{l}\text { Female } \\
\text { No. (\%) }\end{array}$ & & \\
\hline \multicolumn{5}{|c|}{ Nasal septal deviation } \\
\hline Absent & $37(26.6)$ & $48(29.8)$ & $85(28.3)$ & 0.54 \\
\hline Present & $102(73.4)$ & $113(70.2)$ & $215(71.7)$ & \\
\hline \multicolumn{5}{|c|}{ Nasal septal spur } \\
\hline Absent & 88(63.3.) & $110(68.3)$ & $198(66.0)$ & 0.36 \\
\hline Present & $51(36.7)$ & $51(31.7)$ & $102(34.0)$ & \\
\hline \multicolumn{5}{|c|}{ Septal pneumatization } \\
\hline Absent & $114(82)$ & $136(84.5)$ & $250(83.3)$ & 0.569 \\
\hline Present & $25(18)$ & $25(15.5)$ & $50(16.7)$ & \\
\hline \multicolumn{5}{|c|}{ Concha bullosa } \\
\hline Absent & $55(39.6)$ & $62(38.5)$ & $117(39.0)$ & 0.851 \\
\hline Present & $84(60.4)$ & $99(61.5)$ & $183(61.0)$ & \\
\hline \multicolumn{5}{|c|}{ Agger nasi cells } \\
\hline Absent & $37(26.6)$ & $47(29.2)$ & $84(28.0)$ & 0.621 \\
\hline Present & 102(73.4) & $114(70.8)$ & $216(72.0)$ & \\
\hline \multicolumn{5}{|c|}{ Haller cells } \\
\hline Absent & $41(29.5)$ & $47(29.2)$ & $88(29.3)$ & 0.954 \\
\hline Present & $98(70.5)$ & $114(70.8)$ & $114(70.8)$ & \\
\hline \multicolumn{5}{|c|}{ Onodi cells } \\
\hline Absent & 71(51.1) & $95(59.0)$ & $166(55.3)$ & 0.168 \\
\hline Present & $68(48.9)$ & $66(41.0)$ & $134(44.7)$ & \\
\hline \multicolumn{5}{|c|}{ Sphenoidal variants } \\
\hline Absent & 19(13.7) & $45(28)$ & $64(21.3)$ & 0.003 \\
\hline Present & $120(86.3)$ & 116(72) & $236(78.7)$ & \\
\hline \multicolumn{5}{|c|}{ Keros classification } \\
\hline Type I & $54(38.8)$ & $39(24.2)$ & $93(31.0)$ & ${ }^{*}<0.001$ \\
\hline Type II & $78(56.1)$ & $122(75.8)$ & $200(66.7)$ & \\
\hline Type III & $7(5.0)$ & $0(0.0)$ & $7(2.3)$ & \\
\hline \multicolumn{5}{|c|}{ Ethmoidal roof asymmetry } \\
\hline Absent & $66(47.5)$ & $104(64.6)$ & $170(56.7)$ & 0.003 \\
\hline Present & $73(52.5)$ & $57(35.4)$ & $130(43.3)$ & \\
\hline
\end{tabular}

*Fisher 's Exact Test used 
Mucosal abnormalities representing rhinosinusitis were detected in 268 (89.3\%) of 300 patients, including inferior turbinate hypertrophy and mucosal thickening of the sinuses. The prevalence of mucosal thickening was significantly higher in males than females. The relationship between certain anatomic variants and mucosal abnormalities is shown in Tables 3 and 4 . A significant association was found between the middle turbinate variants and the presence of mucosal abnormalities.

Table 3: Association of certain anatomic variants with mucosal thickening of the sinuses.

\begin{tabular}{|c|c|c|c|c|}
\hline \multirow[t]{3}{*}{ Variables } & \multicolumn{2}{|c|}{ Mucosal thickening of the sinuses } & \multirow{3}{*}{$\begin{array}{c}\text { Total }(\mathrm{N}=300) \\
\text { No. }(\%)\end{array}$} & \multirow[t]{3}{*}{$P$ value } \\
\hline & Absent & Present & & \\
\hline & No. $(\%)$ & No. (\%) & & \\
\hline \multicolumn{5}{|l|}{ Gender } \\
\hline Male & $54(38.8)$ & $85(61.2)$ & $139(100)$ & 0.001 \\
\hline Female & $94(58.4)$ & $67(41.6)$ & $161(100)$ & \\
\hline \multicolumn{5}{|c|}{ Nasal septal deviation } \\
\hline Absent & $37(43.5)$ & $48(56.5)$ & $85(100)$ & 0.206 \\
\hline Present & $111(51.6)$ & $104(48.4)$ & $215(100)$ & \\
\hline \multicolumn{5}{|c|}{ Concha bullosa } \\
\hline Absent & $52(44.4)$ & $65(55.6)$ & $117(100)$ & 0.176 \\
\hline Present & $96(52.5)$ & $87(47.5)$ & $183(100)$ & \\
\hline \multicolumn{5}{|c|}{ Agger nasi cells } \\
\hline Absent & $39(46.4)$ & $45(53.6)$ & $84(100)$ & 0.53 \\
\hline Present & $109(50.5)$ & $107(49.5)$ & $216(100)$ & \\
\hline \multicolumn{5}{|c|}{ Haller cells } \\
\hline Absent & $39(44.3)$ & $49(55.7)$ & $88(100)$ & 0.263 \\
\hline Present & $109(51.4)$ & $103(48.6)$ & $212(100)$ & \\
\hline \multicolumn{5}{|c|}{ Onodi cells } \\
\hline Absent & $83(50)$ & $83(50)$ & $166(100)$ & 0.797 \\
\hline Present & $65(48.5)$ & $69(51.5)$ & $134(100)$ & \\
\hline
\end{tabular}

Table 4: Association of certain anatomic variants with inferior turbinate enlargement.

\begin{tabular}{|c|c|c|c|c|}
\hline \multirow[t]{2}{*}{ Variables } & \multicolumn{2}{|c|}{ Inferior Turbinate Enlargement } & \multirow{2}{*}{$\begin{array}{c}\text { Total } \\
\text { No. (\%) }\end{array}$} & \multirow[t]{2}{*}{$P$ value } \\
\hline & $\begin{array}{l}\text { Absent } \\
\text { No. (\%) }\end{array}$ & $\begin{array}{l}\text { Present } \\
\text { No. (\%) }\end{array}$ & & \\
\hline \multicolumn{5}{|l|}{ Gender } \\
\hline Male & $20(14.4)$ & $119(85.6)$ & $139(100)$ & 0.024 \\
\hline Female & $40(24.8)$ & $121(75.2)$ & $161(100)$ & \\
\hline \multicolumn{5}{|c|}{ Nasal septal deviation } \\
\hline Absent & $17(20.5)$ & $66(79.5)$ & $83(100)$ & 0.897 \\
\hline Present & $43(19.8)$ & $174(80.2)$ & $217(100)$ & \\
\hline \multicolumn{5}{|c|}{ Concha bullosa } \\
\hline Absent & $34(29.1)$ & $83(70.9)$ & $117(100)$ & 0.002 \\
\hline Present & $26(14.2)$ & $157(85.8)$ & $183(100)$ & \\
\hline \multicolumn{5}{|c|}{ Agger nasi cells } \\
\hline Absent & $20(23.8)$ & $64(76.2)$ & $84(100)$ & 0.304 \\
\hline Present & $40(18.5)$ & $176(81.5)$ & $216(100)$ & \\
\hline \multicolumn{5}{|c|}{ Haller cells } \\
\hline Absent & $11(12.5)$ & $77(87.5)$ & $88(100)$ & 0.036 \\
\hline Present & $49(23.1)$ & 163(76.9) & $212(100)$ & \\
\hline \multicolumn{5}{|c|}{ Onodi cells } \\
\hline Absent & $36(21.7)$ & $130(78.3)$ & $166(100)$ & 0.41 \\
\hline Present & $24(17.9)$ & $110(82.1)$ & $134(100)$ & \\
\hline
\end{tabular}




\section{Discussion}

The paranasal sinus region is subject to a large variety of lesions. Normal anatomic variants in this region are important as they may have pathological consequences or maybe the source of difficulty/ complication during surgery. Certain anatomic variants are thought to be predisposing factors for the development of sinus diseases, and thus it becomes necessary for the radiologist to be aware of these variants, especially if the patient is a candidate for functional endoscopic sinus surgery (FESS). ${ }^{23}$ The most common anatomic variant in this study was Agger nasi cell $(72 \%)$, similar to a study done in Turkey. ${ }^{6}$ Other authors have reported prevalence rates of $88 \%,{ }^{24} 96.5 \%,{ }^{25}$ and $94.1 \% .{ }^{26}$ The Aggernasi cell (Figure $1 \mathrm{a}$ ) is the most anterior of the anterior ethmoid cells, found anterior and superior to the middle turbinate attachment to the lateral wall. ${ }^{27}$ Enlargement of Agger nasi cells has been found to correlate with a decrease in CT in the anterioposterior size of the nasofrontal recess, involved in the frontal sinus drainage pathway. Failure to address Agger nasi disease can contribute to the failure of the primary surgery. ${ }^{28}$ The second most common anatomic variant was the deviation of the nasal septum. The NSD (Figure $1 \mathrm{a}$ ) is an asymmetric bowing of the nasal cartilaginous septum. Such bowing may compress the middle turbinate in a lateral fashion, which may lead to the narrowing of the middle meatus. ${ }^{27}$ In this study, any deviation from the midline was regarded as NSD without considering the degree of deviation determined by connecting the lines being drawn downward from the crista galli and upward from the nasal eminence, and it was found in $71.7 \%$ of the scans. Earlier studies reported different rates, for example, $89.7 \%$ by Kaya et al., ${ }^{6} 81.8 \%$ by Kaplanoglu et al., ${ }^{29} 68.2 \%$ by Sharma et al., ${ }^{30} 60 \%$ by Reddy et al., ${ }^{31}$ and $48.8 \%$ by Alsowey et al. $^{32}$ Other variants of the nasal septum included septal spur (34\%) and pneumatized septum (17.3\%). In literature, the frequency of pneumatization of the nasal septum is $(0-18) \% .^{6,29,33}$ Haller cells (Figure $1 \mathrm{~b}$ ) are ethmoid air cells that extend laterally over the medial aspect of the roof of the maxillary sinus; they may cause narrowing of the infundibulum. ${ }^{27}$ In the present study, Haller cells were frequent variants and found in $70.5 \%$ of the scans (Figure), but other authors have reported a wide variation in the prevalence rates such as $25 \%,{ }^{1} 9.1 \%,{ }^{33} 8 \%,{ }^{34}$ and $33 \%{ }^{31,35}$ Onodi cell was found in $44.7 \%$ of the scans in the current study. Other studies reported Onodi cell in $8 \%{ }^{1}$ and $14 \%{ }^{6}$ of their samples. Onodi cell is the most posterior ethmoid air cell that extends laterally. This extension is near the carotid canal and close to the optic nerve, which emphasizes the clinical importance of considering this anatomic variation prior to any attempt for invasive intervention. ${ }^{27}$ Middle turbinate or middle concha variants were common in the present study $(81.7 \%)$. Concha bullosa (CB) is one of the most frequently found anatomic variants. The incidence of $\mathrm{CB}$ in the population ranges from 13 to $73 \%$ in literature, ${ }^{36}$ the differences reported may have been influenced by the aeration degree, and lower rates suggest that only large turbinates may have been taken into consideration. The present study has adopted the definition by Zinreich et al., ${ }^{37}$ who have considered any pneumatization degree as CB and was found in $61.4 \%$ of the scans (Figure $1 \mathrm{~b}$ ). Other studies have found a prevalence of $30.6 \%$ by Alsowey et al., ${ }^{32} 31.7 \%$ by Kalaiarasi et al., ${ }^{36} 30 \%$ and $51 \%$ by two different studied in Turkey. ${ }^{6,29}$ The middle turbinate usually curves medially toward the nasal septum. However, the resultant anatomic variant is known as a paradoxical middle turbinate when the turbinate curves laterally. Such a variant can narrow or obstruct the nasal cavity, middle meatus, or infundibulum. ${ }^{27}$ Again, the prevalence reported by different authors may diverge because some consider any involved portion of the turbinate as paradoxical curvature. 
In contrast, others may consider this variation only in cases where the whole turbinate is unusually curved towards the opposite side. In the present study, 57 patients were found with paradoxical middle turbinates (19\%) near to a study done in India $18 \% .{ }^{31}$ Roman et al. ${ }^{1}$ have found this variant in $8 \%$ of their cases, Adeel et al. $^{2}$ in $14.3 \%$ and Kaya et al. ${ }^{6}$ in $4.3 \%$. The uncinate process (UP) is a structure that has multiple variations between individuals. The superior attachment of the UP has three major variations that help determine the anatomic configuration of the frontal recess and its drainage. ${ }^{27}$ The present study investigated the shape and pneumatization of the UP. Elongation of the UP was frequent $(69.7 \%)$. Regarding the depth of olfactory fossa, the most frequent type in this study was Keros Type II in agreement with Keros ${ }^{22}$ and Yadav et al. ${ }^{38}$ According to Keros classification, the depth of the olfactory fossa is 1-3 $\mathrm{mm}$ in Type I, 4-7 $\mathrm{mm}$ in Type $\mathrm{II}$, and 8-16 $\mathrm{mm}$ in Type III based on the height of the lateral lamella, the greater the height of the lateral lamella, the higher the risk of its penetration into the anterior cranial fossa. ${ }^{22}$ Asymmetry in the anterior of the skull base and especially in the ethmoid roof is important for ESS. Intracranial complications appear more frequently on the side in which the ethmoid roof is low. This low-hanging roof may cause cerebrospinal fluid fistula and recurrent meningitis postoperatively. ${ }^{39}$ This study showed asymmetry of the ethmoidal roof in $43.3 \%$ of the 300 scans. The sphenoid bone may be affected by different variants of pneumatization (Figure 2), these have a relevant importance from a clinical and surgical point of view. ${ }^{40}$ Of the 300 scans in the current study $78.7 \%$ showed a form of anatomical variant of the sphenoid sinuses with statistically significant differences between males and females $(P<0.01)$. The current study showed rudimentary or absence of at least one side of the frontal sinuses in $11.7 \%$ of the scans in agreement with Kaya et al. ${ }^{6}$
There were other uncommon variants with crista galli pneumatization in $5.7 \%$, maxillary sinus hypoplasia in $1.3 \%$, and uncinate process pneumatization in $3 \%$ of cases. The dissimilarities observed between our findings and the results of previous investigations may be attributed to racial, geographic, and hereditary disparities, differing sensitivity of data acquisition, and discrepant definitions for a few diagnostic variants. In this study, the frequency of variants did not differ significantly with respect to gender $(P>0.05)$ in agreement with Reddy et al. ${ }^{31}$ and Yadav et al ${ }^{38}$ except for sphenoidal variants along with Keros types and ethmoidal roof asymmetry $(P<0.00)$. Males had a higher prevalence of Keros type III and asymmetry of the ethmoid roof, which makes them more susceptible to operative complications. Therefore, extra care must be taken during surgeries on males the same as in the neighbor Turkish population reported by Kaplanoglu et al. ${ }^{29}$ Mucosal abnormalities were detected in 268 $(89.3 \%)$ of 300 patients, including inferior turbinate hypertrophy and mucosal thickening of the sinuses. The term 'turbinate hypertrophy' was first coined in the late 1800s to describe enlargement of the inferior turbinate, and it remains in common use today. ${ }^{41}$ In the present study, a significant association was found between mucosal abnormalities with each of the gender and middle concha variants, including CB. There are limitations of the present study, mainly because the studied population does not accurately represent the general population. All patients were referred to PNS CT for suspected sinus disease. This is difficult to overcome because a study with a truly randomized population would require subjects to undergo unnecessary radiation exposure and thus contradict the ALARA principle, "as low as reasonably achievable." Some studied used patients referred for the brain, orbit, or dental evaluation as control groups, but this was not done in the current study. 


\section{Conclusion}

Anatomic variants of the paranasal sinus region were common in our population; the most frequent ones were those involving the nasal septum, ethmoid and sphenoid sinuses. The study of these variants is important for the management of paranasal sinus region disease.

\section{Competing interests}

The author declares no competing interests.

\section{References}

1. Roman RA, Hedeşiu M, Gersak M, Fidan F, Băciut $G$, Băciut $M$. Assessing the prevalence of paranasal sinuses anatomical variants in patients with sinusitis using Cone Beam Computer Tomography. Clujul Med 2016; 89(3):419-21.

2. Khojastepour L, Mirhadi S, Mesbahi SA. Anatomical Variations of Ostiomeatal Complex in CBCT of Patients Seeking Rhinoplasty. J Dent (Shiraz) 2015; 16(1):42-8.

3. Azila A, Irfan $M$, Rohaizan $Y$, Shamim AK. The prevalence of anatomical variations in osteomeatal unit in patients with chronic rhinosinusitis. Med J Malaysia 2011; 66:191-4.

4. Stallman JS, Lobo JN, Som PM. The incidence of concha bullosa and its relationship to nasal septal deviation and paranasal sinus disease. AJNR 2004; 25:1613-8.

5. Fadda GL, Rosso S, Aversa S, Petrelli A Ondolo C, Succo G. Multiparametric statistical correlations between paranasal sinus anatomic variations and chronic rhinosinusitis. Acta Otorhinolaryngolltal 2012; 32:244-51.

6. Kaya M, Çankal F, Gumusok M, Apaydin N, Tekdemir I. Role of anatomic variations of paranasal sinuses on the prevalence of sinusitis: Computed tomography findings of 350 patients. Niger J Clin Pract 2017; 20:1481-8.

7. Mathew R, Omami G, Hand A, Fellows D, Lurie A. Cone beam CT analysis of Haller cells: prevalence and clinical significance. Dentomaxillofac Radiol 2013; 42:20130055

8. Nouraei SA, Elisay AR, Dimarco A, Abdi R, Majidi $\mathrm{H}$, Madani $\mathrm{SA}$, et al. Variations in paranasal sinus anatomy: implications for the pathophysiology of chronic rhinosinusitis and safety of endoscopic sinus surgery. J Otolaryngol Head Neck Surg 2009; 38(1):32-7.

9. Tomovic S, Esmaeili A, Chan NJ, Choudhry OJ, Shukla PA, Liu JK, et al. High-resolution computed tomography analysis of the prevalence of Onodi cells. Laryngoscope 2012; 122(7):1470-3.

10. Alkire BC, Bhattacharyya N. An assessment of sinonasal anatomic variants potentially associated with recurrent acute rhinosinusitis. Laryngoscope 2010; 120:631-4.

11. İla K, Yilmaz N, Öner S, Başaran E, Öner Z. Evaluation of superior concha bullosa by computed tomography. Surg Radiol Anat 2018; 40:841-6.

12. Kanowitz SJ, Nusbaum AO, Jacobs JB, Lebowitz RA. Superior turbinate pneumatization in patients with chronic rhinosinusitis: prevalence on paranasal sinus CT. Ear Nose Throat J 2008; 87:578-9.

13. Som PM, Park EE, Naidch TP, Lawson W. Crista galli pneumatization is an extension of the adjacent frontal sinus. Am Soc Neuroradiol 2009; 30:31-3

14. Comer BT, Kincaid NW, Smith NJ,Wallace JH, Kountakis SK.Frontal sinus septations predict the presence of supraorbital ethmoid cells. Laryngoscope 2013; 123:2090-3.

15. Smith KD, Edwards PC, Saini TS, Norton NS. The prevalence of concha bullosa and nasal septal deviation and their relationship to maxillary sinusitis by volumetric tomography. Int J Dent 2010; 2010:9-13.

16. Kim HJ, Jung CM, Lee JW, Tae KY, Kahng H, Sung $\mathrm{KH}$, et al. The relationship between anatomic variations of paranasal sinuses and chronic sinusitis in children. Acta Otolaryngol 2006; 126:1067-72.

17. Mikami T, Minamida $\mathrm{Y}$, Koyanagi I, Baba T, Houkin K. Anatomical variations in pneumatization of the anterior clinoid process. J Neurosurg 2007; 106:170-4.

18. Hamid O, El Fiky L, Hassan O, Kotb A, El Fiky S. Anatomic variations of the sphenoid sinus and their impact on trans-sphenoid pituitary surgery. Skull Base 2008; 18:9-15.

19. Hewaidi G, Omami G. Anatomic variation of sphenoid sinus and related structures in Libyan population: CT scan study. Libyan J Med 2008; 3(3):128-33.

20. Kitaguchi Y, Takahashi Y, Mupas-Uy J, Kakizaki $\mathrm{H}$. Characteristics of Dehiscence of Lamina Papyracea Found on Computed Tomography Before Orbital and Endoscopic Endonasal Surgeries. J Craniofac Surg 2016; 27(7):662-5.

21. Badia L, Lund VJ, Wei W, Ho WK. Ethnic variation in sinonasal anatomy on CT-scanning. Rhinology 2005; 43:210-4.

22. Gupta P, Ramesh P. Radiological observation of ethmoid roof on basis of keros classification and its application in endonasal surgery. Int $\mathrm{J}$ Anat Res 2017; 5:4204-7.

23. Reddy UD, Dev B. Pictorial essay: Anatomical variations of paranasal sinuses on multidetector computed tomography-How does it help FESS surgeons? Indian J Radiol Imaging 2012; 22(4):317-24.

24. Kubota K, Takeno S, Hirakawa K. Frontal recess anatomy in Japanese subjects and its effect on the development of frontal sinusitis: computed 
tomography analysis. J Otolaryngol Head Neck Surg 2015; 44(1):21.

25. Choby G, Thamboo A, Won TB, Kim J, Shih LC, Hwang $\mathrm{PH}$. CT analysis of frontal cell prevalence according to the International Frontal Sinus Anatomy Classification. Int Forum Allergy Rhinol 2018; 8:825-30.

26. Han D, Zhang L, Ge W, Tao J, Xian J, Zhou B. Multiplanar computed tomographic analysis of the frontal recess region in Chinese subjects without frontal sinus disease symptoms. ORL $J$ Otorhinolryngol Relat Spec 2008; 70:104-12

27. Vaid S, Vaid N. Normal Anatomy and Anatomic Variants of the Paranasal Sinuses on Computed Tomography. Neuroimaging Clin N Am 2015; 25(4):527-48.

28. Bradley DT, Kountakis SE. The role of agger nasi air cells in patients requiring revision endoscopic frontal sinus surgery. Otolaryngol Head Neck Surg 2004; 131:525-7.

29. Kayalioglu G, Oyar O, Govsa F. Nasal cavity and paranasal sinus bony variations: a computed tomographic study. Rhinology 2000; 38:108-13.

30. Sharma BN, Pant OB, Lohani B. Computed tomography in the evaluation of pathological lesions of paranasal sinuses. J Nepal Health Res Counc 2015; 13(30):116-20.

31. Reddy A, Kakumanu PK, Kondragunta C, Gandra NR. Role of computed tomography in identifying anatomical variations in chronic sinusitis: An observational study. West Afr J Radiol 2018; 25:65-71.

32. Alsowey AM, Abdulmonaem G, Elsammak A, Fouad $Y$. Diagnostic Performance of Multidetector Computed Tomography (MDCT) in Diagnosis of Sinus Variations. Pol $\mathrm{J}$ Radiol 2017; 82:713-25.

33. Adeel $M$, Shaheryar $M$, Rajput $M$, Akhter $S$, Ikram M, Arain A, et al. Anatomical variations of nose and para-nasal sinuses; CT scan review. JPMA 2013; 63:47-52.

34. Riello APFL, Boasquevisque EM. Anatomical variants of the ostiomeatal complex: tomographic findings in 200 patients. Radiol Bras 2008; 41(3):149-54.

35. Dafalla $S$ Seyed $M$, Elfadil $N$ Elmustafa $O$, Hussain Z. A Computed Tomography-Aided Clinical Report on Anatomical Variations of the Paranasal Sinuses. Int $\mathrm{J}$ Med Res Health Sci 2017; 6(2):24-33.

36. Kalaiarasi R, Ramakrishnan V, Poyyamoli S. Anatomical Variations of the Middle Turbinate Concha Bullosa and its Relationship with Chronic Sinusitis: A Prospective Radiologic Study. Int Arch Otorhinolaryngol 2018; 22(3):297-302.

37. Stallman JS, Lobo JN, Som PM. The Incidence of Concha Bullosa and Its Relationship to Nasal Septal Deviation and Paranasal Sinus Disease. Am J Neuroradiol 2004; 25(9):1613-8.

38. Yadav R, Ansari M, Humagain M, Mishra D. Assessment Of Anatomical Variations Of
Nose And Paranasal Sinuses In Multidetector Computed Tomography. JIOM 2017; 39(1):4954.

39. Gupta AK, Gupta B, Gupta N, Tripathi N. Computed Tomography of Paranasal Sinuses: A Roadmap to Endoscopic Surgery. Clin Rhinollnt J 2012; 5(1):1-10.

40. Gibelli D, Cellina M, Gibelli S, Oliva AG, Termine G, Sforza C. Anatomical variants of sphenoid sinuses pneumatisation: A CT scan study on a Northern Italian population. Radiol Med 2017; 122:575-80.

41. Farmer SEJ, Eccles R. Chronic inferior turbinate enlargement and the implications for surgical intervention. Rhinology 2006; 44:234-8. 